\title{
Roseburia cecicola gen. nov., sp. nov., a Motile, Obligately Anaerobic Bacterium from a Mouse Cecum
}

\author{
THAD B. STANTON $\dagger$ AND DWAYNE C. SAVAGE* \\ Department of Microbiology, University of Illinois, Urbana, Illinois 61801
}

\begin{abstract}
Strain $\mathrm{GM}^{\mathrm{T}}$ (type strain), a motile, obligately anaerobic bacterium, was isolated from scrapings of the cecal mucosa of a conventional laboratory mouse. Strain $\mathrm{GM}^{\mathrm{T}}$ cells were gram-negative, nonsporeforming, slightly curved rods $(0.5$ by 2.5 to $5 \mu \mathrm{m}$ ) with 20 to 35 flagella inserted into the concave side and, occasionally, into the end of each cell. The flagella appeared as a single fascicle when the cells were examined by phase-contrast microscopy. Glycerol, sorbitol, D-glucuronic acid, D-xylose, D-galactose, D-raffinose, D-glucose, D-maltose, cellobiose, sucrose, starch, and glycogen were growth substrates for this organism. Butyrate, ethanol, $\mathrm{CO}_{2}$, and $\mathrm{H}_{2}$ were products of fermentation of glucose and acetate by growing cells. The guanine-plus-cytosine content of the deoxyribonucleic acid of strain $\mathrm{GM}^{\mathrm{T}}$ was $42.3 \mathrm{~mol} \%$, as determined by the thermal denaturation method. The characteristics of this bacterium indicate that it does not belong to any currently recognized genus. Therefore, for this organism we propose a new genus, Roseburia, and a new species, Roseburia cecicola, in the family Bacteroidaceae. A culture of the type strain (strain GM) has been deposited in the American Type Culture Collection under the number ATCC 33874.
\end{abstract}

To begin an investigation of the ecological significance of motility in the bacteria which colonize mammalian gastrointestinal tracts, we recently isolated several morphological types of motile, obligately anaerobic bacteria from scrapings of the cecal mucosa of conventional laboratory mice. Strain $\mathrm{GM}^{\mathrm{T}}$ (type strain), one of the bacteria which we isolated, was a gram-negative, slightly curved, rod-shaped organism with a distinct flagellar arrangement. An analysis of the ultrastructure and physiological characteristics of this bacterium indicated that it could not be assigned to any currently recognized genus of gram-negative, obligately anaerobic bacteria. In this paper, we describe the characteristics of mouse cecal bacterium strain $\mathrm{GM}^{\mathrm{T}}$. In addition, we propose that this bacterium be designated Roseburia cecicola, thus creating a new genus and species in the family Bacteroidaceae.

\section{MATERIALS AND METHODS}

Isolation. $R$. cecicola strain $\mathrm{GM}^{\mathrm{T}}$ was isolated from scrapings of the cecal mucosa of a conventional laboratory mouse (ICr/Br Swiss; Harlan-Sprague-Dawley, Indianapolis, Ind.). Mucosal scrapings were inoculated into one end of a sterile capillary tube filled with VTY broth (see below). Inoculated capillary tubes were incubated horizontally at $37^{\circ} \mathrm{C}$. After $24 \mathrm{~h}$, samples of the broth were taken from the ends of the capillary tubes opposite the inoculated ends. Motile

$\dagger$ Present address: Agricultural Products Section, Pfizer Central Research, Groton, CT 06340. bacteria which had migrated through the broth in the capillary tubes and away from the inoculated ends were in these samples. The samples were inoculated into tubes containing melted $\left(43^{\circ} \mathrm{C}\right)$ VTY agar. The agar was allowed to harden, and the inoculated tubes were incubated at $37^{\circ} \mathrm{C}$. After $24 \mathrm{~h}$ of incubation, motile bacteria were obtained from colonies which had developed in the VTY agar.

Culture conditions and substrate utilization. Unless otherwise indicated, $R$. cecicola was grown anaerobically in prereduced media at $37^{\circ} \mathrm{C}$ in an atmosphere containing $95 \% \mathrm{~N}_{2}$ and $5 \% \mathrm{CO}_{2}$.

VTY medium, which was used for routine cultivation of $R$. cecicola, was based on medium 10 of Caldwell and Bryant (6). VTY medium contained $0.5 \mathrm{~g}$ of yeast extract (BBL Microbiology Systems, Cockeysville, Md.), $1.0 \mathrm{~g}$ of Trypticase peptone (BBL), 1.0 $\mathrm{ml}$ of $0.05 \%(\mathrm{wt} / \mathrm{vol})$ in $0.01 \mathrm{~N} \mathrm{NaOH}, 0.1 \mathrm{~g}$ of $\mathrm{L}$ cysteine hydrochloride $\cdot \mathrm{H}_{2} \mathrm{O}, 0.1 \mathrm{ml}$ of $0.1 \%$ (wt/vol) resazurin, $20 \mathrm{ml}$ of salt solution $\mathrm{A}, 20 \mathrm{ml}$ of salt solution $\mathrm{B}, 56 \mathrm{ml}$ of distilled water, $0.3 \mathrm{ml}$ of VFA solution, $1.0 \mathrm{ml}$ of $5 \%(\mathrm{wt} / \mathrm{vol}) \mathrm{NaHCO}_{3}$, and $2 \mathrm{ml}$ of $10 \%$ (wt/vol) glucose. Salt solution A contained (per $1,000 \mathrm{ml}$ of distilled water) $0.6 \mathrm{~g}$ of $\mathrm{CaCl}_{2} \cdot 2 \mathrm{H}_{2} \mathrm{O}$ and $0.45 \mathrm{~g}$ of $\mathrm{MgSO}_{4}$. Salt solution B contained (per 1,000 $\mathrm{ml}$ of $.05 \mathrm{M}$ potassium phosphate buffer, $\mathrm{pH} 7.4) 4.5 \mathrm{~g}$ of $\mathrm{NaCl}$ and $4.5 \mathrm{~g}$ of $\left(\mathrm{NH}_{4}\right)_{2} \mathrm{SO}_{4}$. VFA solution contained the following acids: acetic, $17 \mathrm{ml}$; propionic, 6 $\mathrm{ml}$; $n$-butyric, $4 \mathrm{ml}$; $n$-valeric, $1 \mathrm{ml}$; isovaleric, $1 \mathrm{ml}$; isobutyric, $1 \mathrm{ml}$; and DL- $\alpha$-methylbutyric, $1 \mathrm{ml}$. In addition, VTY agar contained $0.7 \%$ (wt/vol) Noble agar (Difco Laboratories, Detroit, Mich.), and VTY-ss agar contained $0.4 \%(\mathrm{wt} / \mathrm{vol})$ Noble agar (Difco).

Each medium (without glucose and $\mathrm{NaHCO}_{3}$ ) was adjusted to $\mathrm{pH} 7.4$ and then heated under a $95 \% \mathrm{~N}_{2}$ $5 \% \mathrm{CO}_{2}$ atmosphere until the resazurin indicator became colorless and the agar (when present) was dis- 
solved. The reduced medium was distributed into anaerobic culture tubes ( 18 by $142 \mathrm{~mm}$; Bellco Glass, Inc., Vineland, N.J.; $9.7 \mathrm{ml}$ of medium per tube) either inside an anaerobic chamber (Coy Manufacturing Co., Ann Arbor, Mich.) or while the tubes were being flushed with $95 \% \mathrm{~N}_{2}-5 \% \mathrm{CO}_{2}$, using the procedures described by Hungate (14). The tubes containing the medium were sealed with Neoprene stoppers and autoclaved. After the sterile medium had cooled to room temperature, $0.1 \mathrm{ml}$ of a filter-sterilized $\mathrm{NaHCO}_{3}$ solution $(5 \%, \mathrm{wt} / \mathrm{vol})$ and $0.2 \mathrm{ml}$ of an autoclaved glucose solution $(10 \%$, wt $/ \mathrm{vol})$ were added to each tube. The final pH of VTY broth was 7.0 to 7.3 .

Occasionally, VTY medium was dispensed into culture vessels inside an anaerobic chamber (Coy Manufacturing Co.). Frequently, $R$. cecicola cells were cultured on agar-containing media within this chamber. The chamber was filled with a gas mixture containing $92 \% \mathrm{~N}_{2}, 5 \% \mathrm{CO}_{2}$, and $3 \% \mathrm{H}_{2}$. The $\mathrm{O}_{2}$ content of the atmosphere within the chamber varied between 1 and $15 \mu \mathrm{l} /$ liter, as measured with a Couloximeter trace oxygen monitor (Chemical Sensor Development, Torrance, Calif.).

The ability of $R$. cecicola to utilize various carbon compounds for growth was investigated by inoculating growing cells into VTY broth containing potential substrates in place of glucose. To insure that the growth of the bacterial cells was not inhibited by a potential substrate, cells were also inoculated into VTY broth prepared with both the potential substrate and glucose. Initially, $5 \times 10^{6}$ cells were inoculated into $10 \mathrm{ml}$ of medium in a tube. If growth became visible, cells from the culture medium were transferred (inoculum, 1\%, vol/vol) into fresh medium containing the same substrate. After three transfers, bacterial growth was assessed spectrophotometrically by using a Klett spectrophotometer and a 640-nm filter. The optical density of a culture was equated to the bacterial population density (cells per milliliter) by using a standard curve prepared for cells of $R$. cecicola cultured in VTY medium containing glucose. Bacterial population densities were estimated by direct (PetroffHausser) cell counts. Cells in pairs or chains were counted individually. Except for pectin, all substrates were autoclaved or filter sterilized and added separately to the sterile basal medium. Pectin $(1.0 \mathrm{~g})$ was washed and sterilized on a sterile $0.65-\mu \mathrm{m}$ membrane filter (Millipore Corp., Bedford, Mass.) through which $50 \mathrm{ml}(10 \mathrm{ml}$, five times) of $70 \%$ ethyl alcohol was drawn. The pectin on the filter was placed in a sterile petri plate, dried at $45^{\circ} \mathrm{C}$ for $24 \mathrm{~h}$, and then added to sterile, hot $\left(80^{\circ} \mathrm{C}\right)$ VTY broth. The medium containing the pectin was kept at $80^{\circ} \mathrm{C}$ for $15 \mathrm{~min}$. Cultures of $R$. cecicola on VTY agar plates containing starch were flooded with Lugol iodine and examined for zones of starch hydrolysis (28).

Microscopy. $R$. cecicola cells were examined in wet mount preparations with a Zeiss Universal microscope equipped for phase-contrast microscopy. Photomicrographs of bacterial cells were taken with the same microscope equipped with a Cs-matic shutter assembly and a type C-35 camera attachment. Images were recorded on Kodak 35-mm Panatomic-X film.

Negatively stained bacterial cells and ultrathin sections of positively stained bacteria were examined with a JEOL model JEM-100C electron microscope operating at $80 \mathrm{kV}$. Images were recorded on Kodak type 4489 electron microscope film.

For light microscopy and electron microscopy, $R$. cecicola cells were harvested from broth cultures in the exponential phase of growth (approximately $2 \times$ $10^{8}$ cells per $\mathrm{ml}$ ). A 5 - $\mathrm{ml}$ portion of a culture was centrifuged, $4.5 \mathrm{ml}$ of the supernatant was removed, and the cell pellet was suspended in the remaining 0.5 $\mathrm{ml}$ of culture medium. For light microphotographs, a $2-\mu l$ volume of this suspension was placed on a microscope slide and covered with a glass cover slip ( 22 by $22 \mathrm{~mm}$ ). The cover slip was gently pressed with a tissue, which absorbed the excess fluid at the edges of the cover slip. For electron photomicrographs, 1 drop of the suspension was placed on a 300-mesh, Formvarcoated, carbon-reinforced copper grid. After 90 s the drop was drawn off by gently touching it with tissue paper. The cells remaining were negatively stained by placing on the grid 1 drop of $1 \%$ (wt/vol) phosphotungstic acid ( $\mathrm{pH} \mathrm{6.5).} \mathrm{After} 15$ to $60 \mathrm{~s}$ the liquid was removed from the grid with tissue paper.

Cells to be sectioned for electron microscopy were harvested by centrifuging at $5,000 \times \mathrm{g}$ for $15 \mathrm{~min}$ at $4^{\circ} \mathrm{C}$ $100 \mathrm{ml}$ of a culture in the exponential phase of growth. The resulting supernatant was removed, and the cells in the pellet were gently suspended in $10 \mathrm{ml}$ of $0.5 \%$ (wt/vol) glutaraldehyde. This glutaraldehyde solution and all solutions used for fixing bacterial cells were prepared by adding the chemical fixative to a salt solution which consisted of salt solution $A$ and salt solution B in the same final concentrations as in VTY medium (see above), except that the final phosphate buffer concentration was $0.05 \mathrm{M}$. The cells were then pelleted by centrifugation and suspended in melted $\left(48^{\circ} \mathrm{C}\right) 2 \%(\mathrm{wt} / \mathrm{vol})$ Noble agar. The suspension was poured onto a glass microscope slide. After the agar had solidified, blocks $\left(1 \mathrm{~mm}^{3}\right)$ were cut from the hardened agar with a clean razor blade. The agar blocks containing bacteria were used in all subsequent stages of fixation, dehydration, and embedding. The cells in the agar blocks were fixed for $2 \mathrm{~h}$ in cold $\left(4^{\circ} \mathrm{C}\right)$ $2 \%(\mathrm{wt} / \mathrm{vol})$ glutaraldehyde $(\mathrm{pH} 7.0)$ and then for $2 \mathrm{~h}$ at room temperature in $1 \%(\mathrm{wt} / \mathrm{vol})$ osmium tetroxide (pH 7.3). Fixed cells in the agar blocks were dehydrated in a series of ethanol solutions of increasing concentration, taken through propylene oxide as a transition solvent, and embedded in Medcast (Ted Pella Inc., Tustin, Calif.). Ultrathin sections (60 to $150 \mathrm{~nm}$ ) of the embedded cells were cut with a glass knife on a Reichert Ultratome. These sections were stained with $2 \%(\mathrm{wt} / \mathrm{vol})$ uranyl acetate $(\mathrm{pH} 5.0)$ for $10 \mathrm{~min}$ and then with Reynolds lead citrate for 20 min (21).

Analysis of fermentation products. For quantitative determinations of fermentation products, cells of strain $\mathrm{GM}^{\mathrm{T}}$ were cultured in VTY broth $(200 \mathrm{ml})$ in sealed vessels until the cultures reached the late exponential phase of growth (approximately $5 \times 10^{8}$ cells per $\mathrm{ml}$ ). Because acetic, $n$-butyric, and propionic acids were potential fermentation products of the organism, these fatty acids were omitted from VTY broth in which bacteria were cultured for fermentation analyses, except when acetic acid was being tested as a fermentation substrate. Cells were removed from the culture medium by centrifugation at $5,000 \times g$ for 20 min. The supernatant was adjusted to $\mathrm{pH} 7.5$ and stored frozen at $-25^{\circ} \mathrm{C}$ for future analysis.

Nongaseous fermentation products were determined by various quantitative assays that are used for 
determining fermentation products of spirochetes (8) and by gas-liquid chromatography, as follows. Butyl esters were prepared from the dry salts of fatty acid fermentation products by the method of Salanitro and Muirhead (26), except that the spent culture medium was kept at $\mathrm{pH}$ 7.5. Chloroform samples $(4 \mu \mathrm{l})$ containing butylated fatty acids were anlayzed with a Hewlett-Packard model HP 5830A gas chromatograph equipped with a model 7671 Autosampler. Fatty acid butyl esters were separated on a coiled glass column ( $1.8 \mathrm{~m}$ by $4 \mathrm{~mm}$ ) packed with Chromosorb W (80 to 100 mesh) coated with 10\% OV-101 (Supelco, Inc. Bellefonte, Pa.). Argon was the carrier gas. The column temperature was programmed from 70 to $250^{\circ} \mathrm{C}$. The injection temperature was $235^{\circ} \mathrm{C}$, and the flame ionization temperature was $275^{\circ} \mathrm{C}$.

The concentration of carbon dioxide in the spent culture medium was estimated manometrically. The culture medium was acidified to approximately $\mathrm{pH} 1.0$ with $6 \mathrm{~N} \mathrm{H}_{2} \mathrm{SO}_{4}$ and then made basic ( $\mathrm{pH} 11$ ) with $10 \mathrm{~N}$ $\mathrm{KOH}$. The reagents were injected with syringes through rubber stoppers which sealed the culture vessels. The volume of carbon dioxide in the medium was considered to represent the difference between the volume of gas evolved from the acidified culture medium and the volume remaining after the acidified medium had been made basic. This volume was converted into the concentration of carbon dioxide $\left(\mathrm{HCO}_{3}{ }^{-}\right)$in the medium by using a standard curve relating the volume of gas evolved and the concentration of carbon dioxide in the medium. The standard curve was obtained previously by using culture tubes containing known concentrations of $\mathrm{NaHCO}_{3}$ in sterile VTY broth. The quantity of carbon dioxide evolved by the bacteria was related to the amount of glucose consumed. In all fermentation experiments, glucose was assayed enzymatically (Statzyme; Worthington Diagnostics, Freehold, N.J.).

Antibiotic susceptibility. Dividing cells of strain $\mathrm{GM}^{\mathrm{T}}$ were suspended $\left(10^{6}\right.$ cells per $\left.\mathrm{ml}\right)$ in melted $\left(43^{\circ} \mathrm{C}\right)$ VTY agar in an anaerobic chamber. Samples $(20 \mathrm{ml})$ of this suspension was placed in sterile petri plates. After the agar medium had solidified, sterile antibiotic disks (Dispenso-O-Disc; Difco) were placed onto the agar surfaces, and the plates were incubated at $37^{\circ} \mathrm{C}$. After $24 \mathrm{~h}$ of incubation, zones of growth inhibition were observed around disks containing antibiotics to which the organism was susceptible. The diameters of the zones of inhibition were measured, and inhibition was estimated (e.g., slight inhibition, zone $<15 \mathrm{~mm}$ in diameter; moderate inhibition, 15 to $25 \mathrm{~mm}$; strong inhibition, $>25 \mathrm{~mm}$ ).

Determination of the $G+C$ content of $R$. cecicola DNA. Deoxyribonucleic acid (DNA) was extracted from freeze-dried $R$. cecicola cells as described previously for other bacteria (1). The temperature midpoint of thermal denaturation of the DNA was determined (17), and from this value, the guanine-plus-cytosine $(\mathrm{G}+\mathrm{C})$ content was calculated by using the equation of De Ley (9). Escherichia coli DNA (G+C content, $50 \pm$ $1 \mathrm{~mol} \%$ ) was used as a standard in these determinations.

\section{RESULTS}

Morphology and growth characteristics. When cultured in VTY broth, $R$. cecicola cells were slightly curved rods (banana shaped) which measured 0.5 by 2.5 to $5 \mu \mathrm{m}$ (Fig. 1). The cells were actively motile throughout growth in VTY broth. In the late exponential and early stationary phases of growth, the bacteria clumped and settled out of the culture medium. Cell clumping appeared to result when the flagella of different cells tangled.

A distinct feature of $R$. cecicola was a single bundle or fascicle of flagella which was present on virtually every cell examined by phase-contrast microscopy (Fig. 1). The fascicle was always near the end of the cell and usually extended from the concave side; in electron micrographs it appeared to consist of 20 to 35 flagella, which were randomly inserted (Fig. 2). Every cell had unilateral flagella. Occasionally, a cell also had flagella at one end (Fig. 2); cells with these terminal flagella were generally longer than average.

$R$. cecicola cells in the exponential phase of growth $\left(10^{8}\right.$ cells per $\left.\mathrm{ml}\right)$ and in the early stationary phase $\left(5 \times 10^{8}\right.$ cells per $\left.\mathrm{ml}\right)$ in VTY broth were gram negative (29). Before Gram staining, $R$. cecicola cells were combined with cells of bacteria having known Gram reactions. The control bacteria used were Escherichia coli, Lactobacillus fermentum, and Streptococcus $\mathrm{sp}$

Electron micrographs of ultrathin sections of cells (Fig. 3) indicated that the cell envelope of $R$. cecicola was multilayered, which is typical of gram-negative bacteria. The limiting boundary of the cells had the trilaminar structure of an outer (unit) membrane. Thus, microscope observations confirmed that $R$. cecicola is a gramnegative bacterium.

In VTY agar plates prepared by inoculating cells into melted agar medium, dispensing $15-\mathrm{ml}$ portions into petri plates, and allowing the agar to solidify, colonies were visible after $18 \mathrm{~h}$ of incubation at $37^{\circ} \mathrm{C}$. After $48 \mathrm{~h}$ of incubation, in plates containing approximately 100 colonies, the colonies within the agar were $1 \mathrm{~mm}$ in diameter, brownish white, and lens shaped. Occasionally a colony within the agar was surrounded with a gas bubble that split the agar. The colonies on the agar surface were white, circular with smooth edges, and 1.5 to $3 \mathrm{~mm}$ in diameter and had a granular appearance. These surface colonies were mucoid in texture.

$R$. cecicola did not grow in an air atmosphere or in regions of VTY agar in which the resazurin indicator became oxidized. Growth did not occur on VTY agar plates streaked with bacterial cells and incubated at $37^{\circ} \mathrm{C}$ in a GasPak anaerobic container (BBL). Thus, $R$. cecicola behaved as an obligate anaerobe.

Maximum population levels $\left(5 \times 10^{8}\right.$ cells per $\mathrm{ml}$ ) after $24 \mathrm{~h}$ of incubation in VTY broth were 

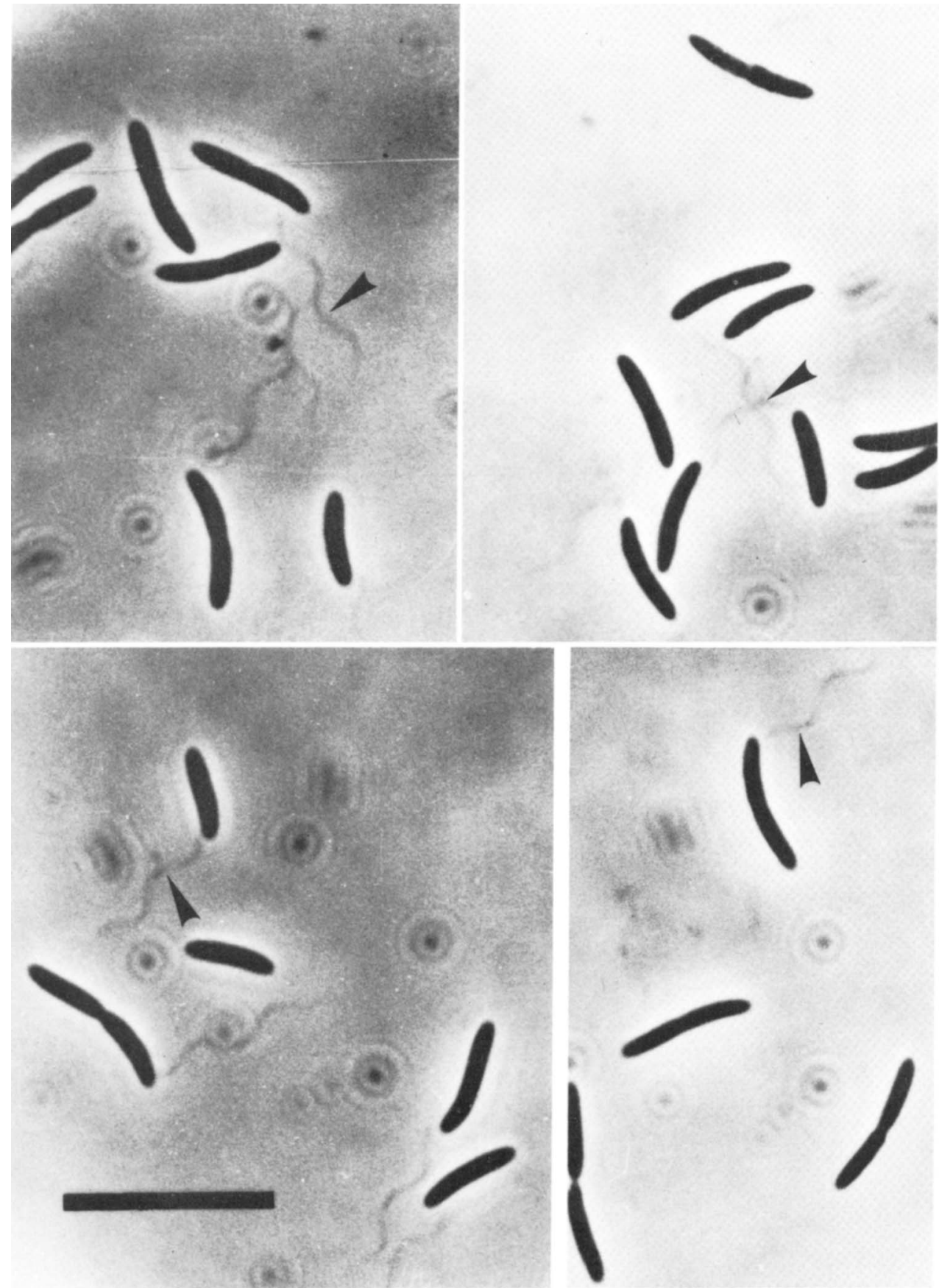

FIG. 1. Phase-contrast micrographs of $R$. cecicola strain $\mathrm{GM}^{\mathrm{T}}$ cells (wet mount preparations). Cells were cultured in VTY broth and were in the exponential phase of growth. Each cell had a fascicle of flagella (arrowheads). Bar $=5 \mu \mathrm{m}$.

obtained at $37^{\circ} \mathrm{C}$. Similar final cell densities were observed at $30^{\circ} \mathrm{C}$ after 48 to $72 \mathrm{~h}$ of incubation. No growth was observed at 22 or $45^{\circ} \mathrm{C}$ even after prolonged incubation. Spore formation was nev- er observed in cultures growing in VTY broth or in chopped meat broth (13).

Substrate utilization. Certain polysaccharides, monosaccharides, disaccharides, and sugar al- 


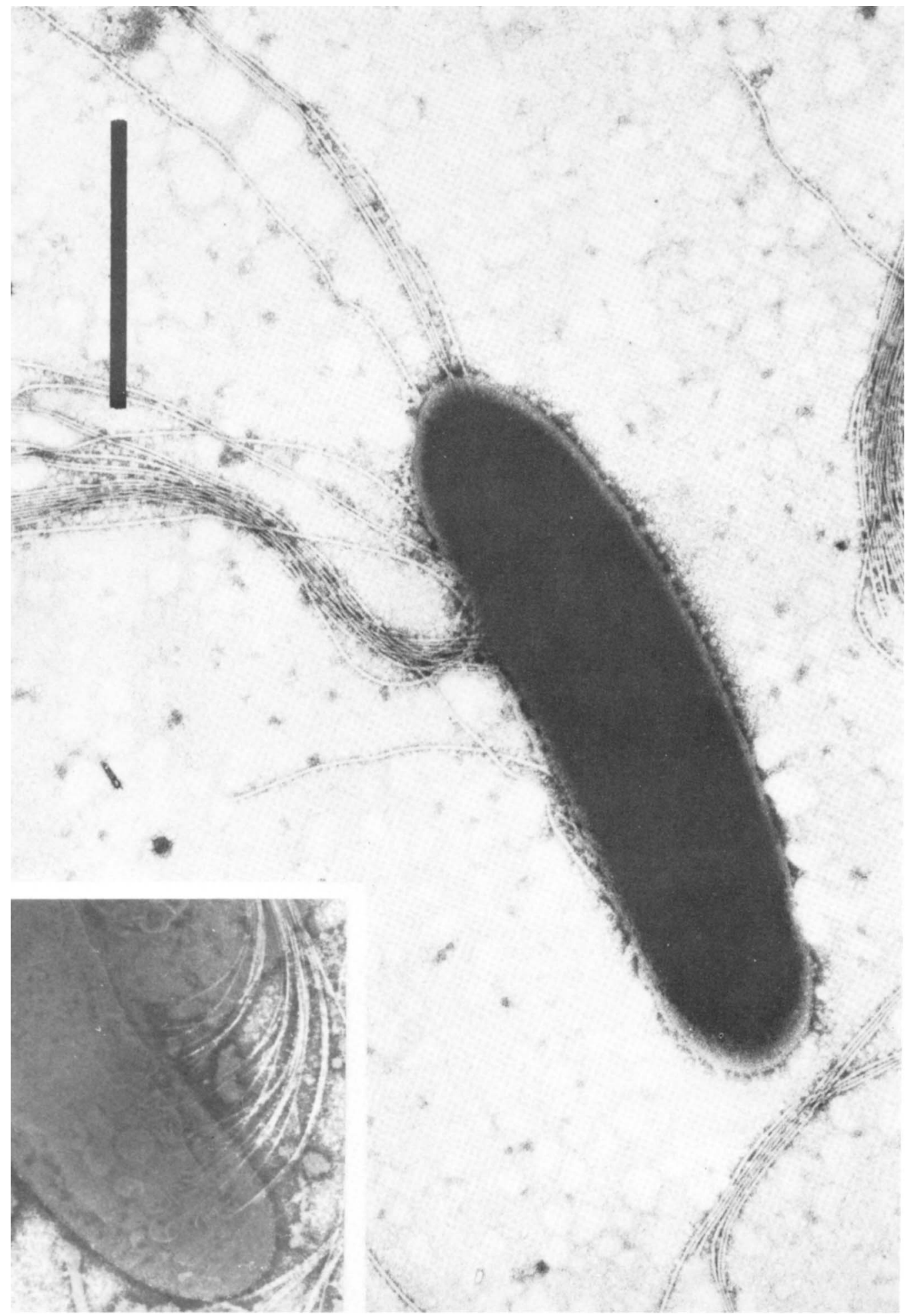

FIG. 2. Electron micrographs of $R$. cecicola cells stained with phosphotungstic acid. A total of 20 to 35 flagella are attached randomly (inset) along one side and one end of each cell. Bar $=1 \mu \mathrm{m}$. 


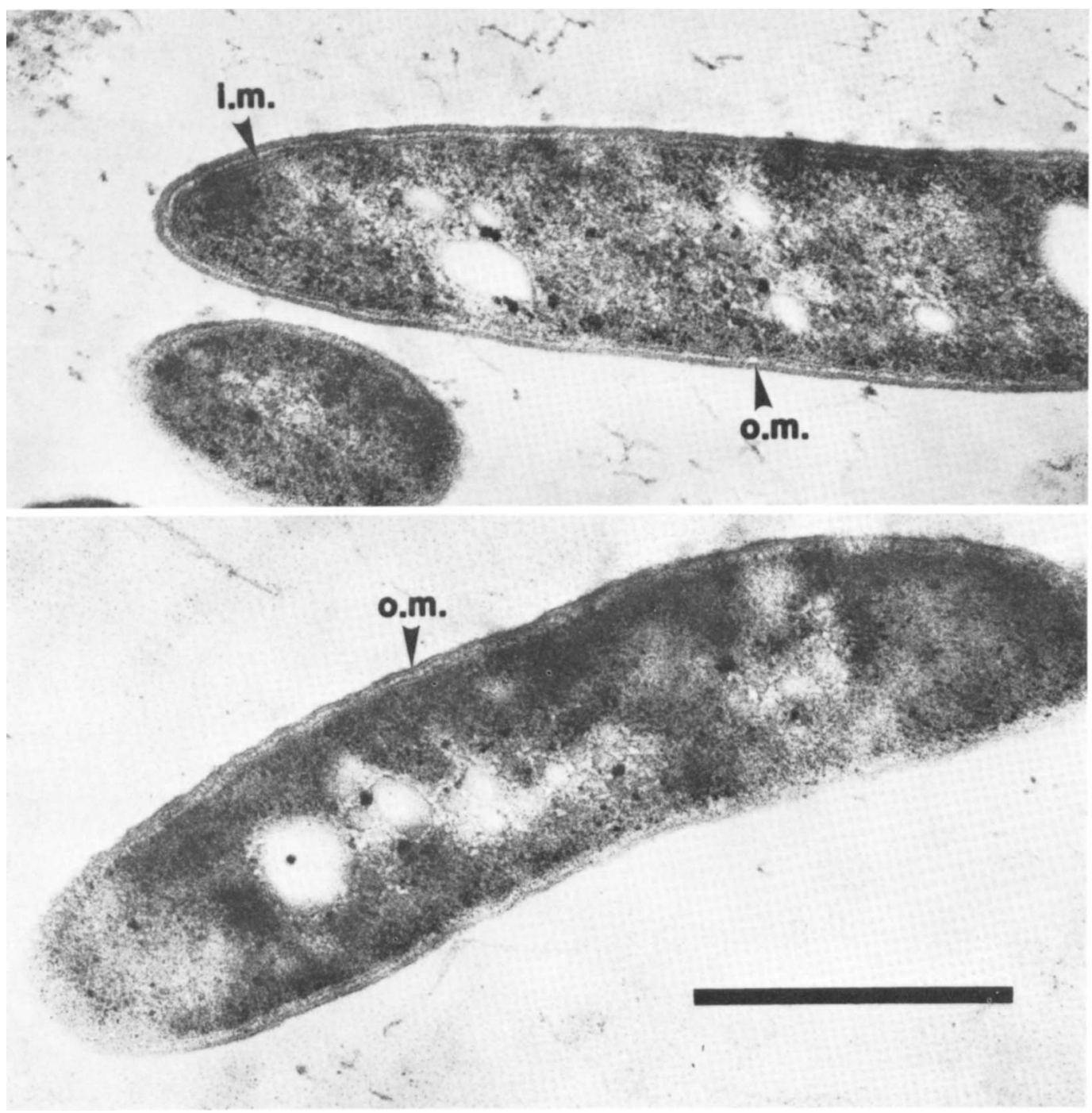

FIG. 3. Ultrathin sections of $R$. cecicola cells stained with uranyl acetate and lead citrate. The inner membranes (i.m.) and outer membranes (o.m.) are typical of gram-negative bacteria. Bar $=0.5 \mu \mathrm{m}$.

cohols served as fermentable substrates for $R$. cecicola (Table 1). Final cell densities (growth yields) were determined by direct (PetroffHausser) microscope counts of cultures for each substrate. $R$. cecicola cells hydrolyzed starch with cell-free amylases, as described below. On starch agar plates flooded with an iodine solution, cleared zones extended up to $5 \mathrm{~mm}$ away from the colonies or growing streaks of bacteria, an indication that $R$. cecicola amylases are extracellular enzymes which diffuse through the agar. The synthesis of amylases was not repressed in cells grown on glucose, xylose, or cellobiose inasmuch as starch was hydrolyzed by cells cultured on plates containing both starch and these soluble sugars at final concentrations of $0.5 \%(\mathrm{wt} / \mathrm{vol})$.

Products of glucose fermentation by growing cells. Cells of $R$. cecicola growing in VTY broth consumed glucose and acetate in equimolar amounts and produced large amounts of butyrate and carbon dioxide (Table 2). Ethyl alcohol was produced in small amounts. In addition to carbon dioxide, another gas which was insoluble in the culture medium at $\mathrm{pH} 11$ was evolved, but this gas was not assayed in our investigation. In more recent studies at the Virginia Polytechnic Institute and State University Anaerobe Labora- 
TABLE 1. Utilization of carbon compounds by growing cells of $R$. cecicola ${ }^{a}$

\begin{tabular}{|c|c|c|}
\hline Compound ${ }^{b}$ & $\begin{array}{c}\text { Population } \\
\text { doubling } \\
\text { time (h) }\end{array}$ & $\begin{array}{l}\text { Growth yield } \\
\left.\text { (cells } / \mathrm{ml}, \times 10^{8}\right)\end{array}$ \\
\hline Glycerol & $5-6$ & 1.4 \\
\hline Sorbitol & 2.5 & 2.5 \\
\hline D-Glucuronic acid & $5-6$ & 4.0 \\
\hline D-Xylose & 2.0 & 9.5 \\
\hline D-Galactose & 2.0 & 6.5 \\
\hline D-Raffinose & 3.0 & 4.7 \\
\hline D-Glucose & 2.0 & 5.7 \\
\hline D-Maltose & 2.5 & 4.5 \\
\hline Cellobiose & 2.0 & 4.0 \\
\hline Sucrose $(0.3 \%, \mathrm{wt} / \mathrm{vol})$ & 4.0 & 9.5 \\
\hline Soluble starch $(0.3 \%, \mathrm{wt} / \mathrm{vol})$ & 2.5 & 4.5 \\
\hline Glycogen & 2.0 & 5.4 \\
\hline
\end{tabular}

${ }^{a}$ The following substrates did not support growth: cellulose (filter paper); methylcellulose; gelatin; chondroitin $(0.3 \%, \mathrm{wt} / \mathrm{vol})$; porcine gastric mucin $(0.3 \%$, $\mathrm{wt} / \mathrm{vol})$; gum xanthan $(0.3 \%$, wt $/ \mathrm{vol})$; gum arabic $(0.3 \%, \mathrm{wt} / \mathrm{vol})$; esculin $(0.3 \%, \mathrm{wt} / \mathrm{vol})$; inulin $(0.3 \%$, wt/vol); D-ribose; sodium lactate; $l$-arginine $(0.3 \%$, wt/ vol); $N$-acetyl-D-galactosamine; $N$-acetyl- $d$-glucosamine; dulcitol; trehalose; sodium pyruvate; sodium citrate; ethyl alcohol $(0.3 \%$, wt $/$ vol $)$; hyaluronate $(0.3 \%, \mathrm{wt} / \mathrm{vol})$; pectin; fructose; salicin $(0.2 \%)$; and $d$ galacturonic acid. Sodium pyruvate prevented growth of strain $\mathrm{GM}^{\mathrm{T}}$ on glucose-containing medium, and cultures grew more slowly on glucose-containing medium when sodium citrate was included in the medium.

${ }^{b}$ Solutions of the compounds were sterilized separately, and each compound was added at a final concentration of $0.5 \%(\mathrm{wt} / \mathrm{vol})$, unless otherwise indicated.

${ }^{c}$ The minimum detectable growth was $2 \times 10^{7}$ cells per $\mathrm{ml}$. No growth was detected in cultures lacking a carbon compound. tory in Blacksburg, $\mathrm{Va}$., $\mathrm{H}_{2}$ has been detected as a product of glucose fermentation. There was no odor of $\mathrm{H}_{2} \mathrm{~S}$ in cultures of $R$. cecicola.

Other characteristics. Under our assay conditions, $R$. cecicola cells were strongly inhibited by chloramphenicol ( $30 \mu \mathrm{g} /$ disk), erythromycin $(15 \mu \mathrm{g} / \mathrm{disk})$, novobiocin (30 $\mu \mathrm{g} / \mathrm{disk})$, and vancomycin $(30 \mu \mathrm{g} / \mathrm{disk})$, moderately inhibited by penicillin $(10 \mu \mathrm{g} / \mathrm{disk})$ and polymyxin $\mathrm{G}(300$ $\mu \mathrm{g} /$ disk), and slightly inhibited by tetracycline $(30 \mu \mathrm{g} / \mathrm{disk})$ and neomycin $(30 \mu \mathrm{g} / \mathrm{disk})$. $R$. cecicola cells were not inhibited by nalidixic acid $(30$ $\mu \mathrm{g} /$ disk). Catalase was not detected. In two determinations by the thermal denaturation method the $\mathrm{G}+\mathrm{C}$ content of DNA from $R$. cecicola $\mathrm{GM}^{\mathrm{T}}$ strain cells averaged $42.3 \mathrm{~mol} \%$ (41.7 and $42.9 \mathrm{~mol} \%$ ).

\section{DISCUSSION}

We believed that DNA base composition, flagellar arrangement, and the fermentation of glucose and acetate to yield large quantities of butyrate were relevant to taxonomic designation of strain $\mathrm{GM}^{\mathrm{T}}$. Butyrate was the only acid produced. On the basis of these characteristics, cecal bacterial strain $\mathrm{GM}^{\mathbf{T}}$ does not belong to any previously described genus of gram-negative, nonsporeforming, obligately anaerobic bacteria.

Unilateral flagella are a characteristic of gramnegative bacteria belonging to the genera Acetivibrio (22), Pectinatus (16), Selenomonas (15), and Syntrophomonas (18). Strain $\mathrm{GM}^{\mathrm{T}}$ differs from species in each of these genera in either DNA base composition, flagellar arrangement, substrates fermented, glucose fermentation

TABLE 2. Products of glucose metabolism in growing cells of $R$. cecicola

\begin{tabular}{lccccc}
\hline Compound & $\begin{array}{c}\text { Amt in uninocu- } \\
\text { lated medium } \\
(\mu \mathrm{mol} / 100 \mathrm{ml} \\
\text { of medium) }\end{array}$ & $\begin{array}{c}\text { Amt in medium after } \\
\text { growth of } R \text {. cecicola } \\
(\mu \mathrm{mol} / 100 \mathrm{ml} \text { of medium })\end{array}$ & $\begin{array}{c}\text { Amt of substrate } \\
\text { utilized } \\
(\mu \mathrm{mol} / 100 \mathrm{ml} \\
\text { of medium })^{b}\end{array}$ & $\begin{array}{c}\text { Amt of product released } \\
(\mu \mathrm{mol} / 100 \mathrm{ml} \text { of medium })^{c}\end{array}$ & $\begin{array}{c}\text { Amt per } 100 \\
\text { mol of glucose } \\
(\mathrm{mol})^{d}\end{array}$ \\
\hline Acetate & 950 & 300 & 650 & & 100 \\
Glucose & 1,050 & 410 & 640 & 990 & 100 \\
$n$-Butyrate & 10 & 1,000 & & 80 & 154 \\
Ethanol & 92 & 172 & & 12 & 240 \\
$\mathrm{CO}_{2}{ }^{e}$ & & & & & \\
\hline
\end{tabular}

${ }^{a}$ Cells were grown in VTY medium. Formate, isobutyrate, $n$-valerate, isovalerate, and succinate were detected in equimolar amounts both in uninoculated VTY medium and in $R$. cecicola culture medium. Lactate, propionate, and pyruvate were not detected or were detected in trace amounts $(<25 \mu \mathrm{mol} / 100 \mathrm{ml}$ of medium $)$ both in uninoculated VTY medium and in spent culture medium.

${ }^{b}$ Calculated by subtracting the amount of compound in the medium after $R$. cecicola growth from the amount in uninoculated medium.

${ }^{c}$ Calculated by subtracting the amount of compound in uninoculated medium from the amount in the medium after $R$. cecicola growth.

${ }^{d}$ As calculated from the amounts of compounds per $100 \mathrm{~mol}$ of glucose, the glucose carbon plus the acetate carbon in the products totaled $100 \%$, and the oxidation-reduction balance was 1.5 .

${ }^{e} \mathrm{CO}_{2}$ production by $R$. cecicola was determined with cultures that were different from the cultures used to determine the other products. In six separate cultures $R$. cecicola cells consumed an average of $450 \mu \mathrm{mol}$ of glucose per $100 \mathrm{ml}$ of medium and produced $1,100 \mu \mathrm{mol}$ of $\mathrm{CO}_{2}$ per $100 \mathrm{ml}$ of medium. 
TABLE 3. Characteristics that are useful in differentiating obligately anaerobic, gram-negative, nonsporeforming, curved bacteria with multiple, unilateral flagella ${ }^{a}$

\begin{tabular}{|c|c|c|c|c|}
\hline Characteristic & $\begin{array}{l}\text { R. cecicola } \\
\text { strain } \mathrm{GM}^{\mathrm{T} b}\end{array}$ & $\begin{array}{l}\text { Selenomonas } \\
\text { ruminantium }\end{array}$ & $\begin{array}{l}\text { Acetivibrio } \\
\text { ethanolgignens }{ }^{d}\end{array}$ & $\begin{array}{c}\text { Pectinatus } \\
\text { cerevisiiphilus }\end{array}$ \\
\hline \multicolumn{5}{|l|}{ Flagella } \\
\hline No./cell & $20-35$ & 16 & $10-15$ & $10-23+$ \\
\hline Location & Subpolar & Central & & \\
\hline Arrangement & Fascicle & Tuft & Fascicle & Separate, comblike \\
\hline \multicolumn{5}{|l|}{ Cell dimensions } \\
\hline Width $(\mu \mathrm{m})$ & 0.5 & $0.9-1.1$ & $0.5-0.9$ & $0.7-0.8$ \\
\hline Length $(\mu \mathrm{m})$ & $2.0-5.0$ & $3.0-6.0$ & $1.5-2.5$ & $2.0-32.0$ \\
\hline Isolation source & Mouse cecum & Rumen & $\begin{array}{l}\text { Colons of } \\
\text { dysenteric swine }\end{array}$ & Spoiled beer \\
\hline $\mathrm{G}+\mathrm{C}$ content $(\mathrm{mol} \%)$ & $42.3^{f}$ & $54^{g}$ & $40^{f}$ & $39.8^{g}$ \\
\hline \multicolumn{5}{|l|}{ Substrate utilization ${ }^{h}$} \\
\hline Cellobiose & $+^{i}$ & + & - & + \\
\hline Esculin hydrolysis & - & + & - & - \\
\hline Glycerol & + & \pm & - & + \\
\hline Glycogen & + & ND & ND & ND \\
\hline Lactate & - & \pm & - & + \\
\hline Pyruvate & - & + & + & ND \\
\hline Raffinose & + & + & - & - \\
\hline Ribose & - & + & - & $w$ \\
\hline Salicin & - & + & + & - \\
\hline Sorbitol & + & - & - & + \\
\hline Sucrose & + & + & - & - \\
\hline Starch hydrolysis & + & + & - & - \\
\hline Xylose & + & + & - & $w$ \\
\hline \multicolumn{5}{|c|}{ Glucose fermentation products } \\
\hline Formate & - & - & $\operatorname{Tr}$ & - \\
\hline Acetate & - & + & + & + \\
\hline Propionate & - & + & - & + \\
\hline Lactate & - & + & - & + \\
\hline Butyrate & + & - & - & - \\
\hline Succinate & - & - & - & + \\
\hline Ethanol & $\operatorname{Tr}$ & - & \pm & - \\
\hline $\mathrm{CO}_{2}$ & + & + & \pm & - \\
\hline $\mathrm{H}_{2}$ & + & + & + & - \\
\hline
\end{tabular}

${ }^{a}$ Syntrophomonas wolfei is also an obligately anaerobic, gram-negative, nonsporeforming curved bacterium with multiple, unilateral flagella. This organism is recovered from sewage sludge or dirty water, however, and has not been isolated in pure culture. Moreover, its cells have only two to eight separate flagella (18).

${ }^{b}$ Data from this study.

c Data from references 15 and 22.

${ }^{d}$ Data from reference 22.

${ }^{e}$ Data from references 16 and 22.

${ }^{f}$ Determined by the thermal denaturation method.

${ }^{8}$ Determined by the buoyant density method.

${ }^{h}$ All four species utilize galactose, glucose, and maltose.

${ }^{i}+$, Substrate utilized or product detected; - , substrate not utilized or product not detected; \pm , variable results (strain-dependent reaction); w, weak reaction; $\mathrm{Tr}$, product detected in trace amounts; ND, not determined.

products, or environmental source of isolation (Table 3). Of the bacteria described in Table 3, only strain $\mathrm{GM}^{\mathrm{T}}$ produces butyrate from glucose fermentation.

Butyrate is a major product of glucose fermentation by gram-negative, rod-shaped anaerobes belonging to the genera Butyrivibrio and Fusobacterium $(2,19)$. Cells of Butyrivibrio fibrisolvens, the type species of the genus Butyrivibrio, have cell walls that are gram positive in ultrastructure, even though they give a gram-nega- tive staining reaction (7). The cell walls of strain $\mathrm{GM}^{\mathrm{T}}$ are gram negative (Fig. 2). Thus, it would be inappropriate to assign strain $\mathrm{GM}^{\mathrm{T}}$ and $B$. fibrisolvens to the same genus.

Bacteria belonging to the genus Fusobacterium produce butyrate (19). However, the $\mathrm{G}+\mathrm{C}$ contents of the DNAs of most species of Fusobacterium are in the range from 26 to $34 \mathrm{~mol} \%$ (19), appreciably lower than the $G+C$ content of strain $\mathrm{GM}^{\mathrm{T}}$ DNA.

On the basis of the considerations described 
TABLE 4. Characteristics that differentiate the genus Roseburia from currently recognized genera of obligately anaerobic, nonsporeforming, gramnegative, rod-shaped bacteria ${ }^{a}$

\begin{tabular}{|c|c|c|}
\hline Genus & $\begin{array}{l}\text { Characteristics different from } \\
\text { Roseburia }{ }^{b}\end{array}$ & $\begin{array}{l}\text { Refer- } \\
\text { ence }\end{array}$ \\
\hline Bacteroides & $\begin{array}{l}\text { Butyrate not a major } \\
\text { product; motility, if } \\
\text { present, by peritrichous } \\
\text { flagella }\end{array}$ & 12 \\
\hline Fusobacterium & $\begin{array}{l}\mathrm{G}+\mathrm{C} \text { content of } \mathrm{DNA} \text { for } \\
\text { most species, } 26-34 \\
\text { mol\%; motility, if present } \\
\text { by peritrichous flagella }\end{array}$ & 19 \\
\hline Leptotrichia & $\begin{array}{l}\text { Lactate is the only major } \\
\text { fermentation acid; } \\
\text { butyrate not produced; } \\
\text { G+C content of DNA, } \\
31-34 \text { mol } \%\end{array}$ & 23 \\
\hline Desulfovibrio & $\begin{array}{l}\text { Respire anaerobically by } \\
\text { reducing sulfur } \\
\text { compounds to } \mathrm{H}_{2} \mathrm{~S}\end{array}$ & 20 \\
\hline Butyrivibrio & $\begin{array}{l}\text { B. fibrisolvens (type species) } \\
\text { is gram-positive in } \\
\text { ultrastructure }\end{array}$ & 2 \\
\hline Succinivibrio & $\begin{array}{l}\text { Butyrate not produced; } \\
\text { motility by monotrichous } \\
\text { flagellum }\end{array}$ & 3 \\
\hline Succinimonas & $\begin{array}{l}\text { Butyrate not produced; } \\
\text { motility by monotrichous } \\
\text { flagellum }\end{array}$ & 4 \\
\hline Lachnospira & $\begin{array}{l}\text { Butyrate not produced; } \\
\text { motility by single, lateral } \\
\text { to subterminal flagellum }\end{array}$ & 24 \\
\hline Selenomonas & $\begin{array}{l}\text { Butyrate not produced; } \\
\text { G+C content of DNA, } \\
53-61 \text { mol } \%\end{array}$ & 5 \\
\hline
\end{tabular}

${ }^{a}$ More recently characterized gram-negative, nonsporeforming, rod-shaped, obligate anaerobes are compared with $R$. cecicola in Table 3 .

${ }^{b}$ Roseburia ( $R$. cecicola strain $\mathrm{GM}^{\mathrm{T}}$ ) is motile by means of 20 to 35 flagella in a single, subterminal fascicle, consumes glucose and acetate, and produces $\mathrm{H}_{2}, \mathrm{CO}_{2}$, ethanol, and butyrate (the only acid product). The $\mathrm{G}+\mathrm{C}$ content of -its DNA is $42.3 \mathrm{~mol} \%$, as determined by the thermal denaturation method.

above, we feel that strain $\mathrm{GM}^{\mathrm{T}}$ represents a new genus. For this genus we propose the name Roseburia (Rose.bur'.i.a. M.L. fem. n. Roseburia in honor of Theodor Rosebury, an American microbiologist who studied and described microorganisms indigenous to humans [25]). We further propose the species name $R$. cecicola (ce.ci.co'la. M.L.n. cecum blind pouch; L.v. suff. cola, from L.v. colo dwell; cecicola cecum dweller). The description of the characteristics of this organism will be modified as additional strains are isolated and studied. Inasmuch as $R$. cecicola is a gram-negative, obligately anaerobic, nonsporeforming, rod-shaped bacterium that was isolated from a mouse intestinal tract, we feel that the genus Roseburia is appropriately assigned to the family Bacteroidaceae (11). In Tables 3 and 4 we list characteristics which differentiate the genus Roseburia from other genera of the Bacteroidaceae and from unaffiliated genera of gram-negative, nonsporeforming, obligately anaerobic, rod-shaped bacteria.

$R$. cecicola appears to exist at high population levels in the ceca of adult laboratory mice in different geographical locations. We have isolated starch-hydrolyzing bacteria morphologically similar to $R$. cecicola from cecal homogenates of laboratory mice from different commercial suppliers. These animals were housed separately from the mice, one of which yielded the organism finally named $R$. cecicola. In addition $R$. cecicola is indistinguishable morphologically from the tapered rod-shaped organisms with subpolar flagella depicted several years ago by Gordon and Dubos in micrographs of mouse cecal homogenates (10). Thus, a number of observations suggest that $R$. cecicola is indigenous to mouse gastrointestinal tracts (27).

Roseburia gen. nov. Slightly curved rodshaped cells ( 0.5 by 2.5 to $5 \mu \mathrm{m}$ ) occur singly and in pairs. Actively motile at $37^{\circ} \mathrm{C}$ in anaerobic broth by means of 20 to 35 flagella which are inserted along the concave side and occasionally along one end of the cell. The flagella appear as a single, subterminal fascicle when cells are examined by phase-contrast microscopy. Gram-negative, as determined by the staining reaction and by electron microscopy of ultrathin cell sections. Cells do not form spores.

Optimum growth in VTY broth (final cell density, $5 \times 10^{8}$ cells per ml; population doubling time, $2 \mathrm{~h}$ ) at $37^{\circ} \mathrm{C}$. Grows at $30^{\circ} \mathrm{C}$ but not at 22 or $45^{\circ} \mathrm{C}$. Cultured in VTY broth (medium containing volatile fatty acids, yeast extract, Trypticase peptone, inorganic salts, hemin, and glucose) under anaerobic conditions $\left(95 \% \mathrm{~N}_{2-}\right.$ $5 \% \mathrm{CO}_{2}$ atmosphere). No growth occurs aerobically. Subsurface colonies in VTY medium supplemented with $0.7 \%$ Noble agar are $1 \mathrm{~mm}$ in diameter, brownish white, lens shaped, and occasionally surrounded by gas pockets which split the agar medium. Surface colonies are white, mucoid, granular in appearance, 1.5 to 3 $\mathrm{mm}$ in diameter, and circular with smooth edges.

Butyrate is the major or sole acid product of glucose fermentation. Acetate is utilized during glucose fermentation. The products of growing cells (in micromoles per $100 \mu \mathrm{mol}$ of glucose and $100 \mu \mathrm{mol}$ of acetate utilized) are as follows: butyrate, 154; ethanol, $12 ; \mathrm{CO}_{2}, 240 ; \mathrm{H}_{2}$, amount undetermined.

Chemoorganotrophic, catalase negative, obligate anaerobe. The $\mathrm{G}+\mathrm{C}$ content of strain $\mathrm{GM}^{\mathrm{T}}$ DNA is $42.3 \mathrm{~mol} \%$ as determined by the thermal 
denaturation method. Isolated from mouse cecal mucosa.

Type species: $R$. cecicola.

Roseburia cecicola sp. nov. Growing cells of $R$. cecicola ferment glycerol, sorbitol, D-glucuronic acid, D-xylose, D-galactose, D-raffinose, D-glucose, D-maltose, cellobiose, sucrose, soluble starch, and glycogen. Starch is hydrolyzed by cell-free amylases. Does not ferment cellulose, gelatin, chondroitin, porcine gastric mucin, gum xanthan, gum arabic, esculin, inulin, D-ribose, lactate, L-arginine, $N$-acetyl-D-glucosamine, $N$ acetyl-D-galactosamine, dulcitol, trehalose, lactose, pyruvate, citrate, ethyl alcohol, hyaluronate, pectin, fructose, salicin, or D-galacturonic acid. The other characteristics of this species are the same as those of the genus because $R$. cecicola is presently the only species in the genus. The type strain is strain GM, the only strain which has been characterized. A culture of $R$. cecicola has been deposited with the American Type Culture Collection, Rockville, Md., under the number ATCC 33874.

\section{ACKNOWLEDGMENTS}

We acknowledge the technical assistance of Ed Violante in obtaining electron micrographs of $R$. cecicola and express appreciation to R. B. Hespell for the gas-liquid chromatography analysis of fermentation end products and to E. Stockebrandt for DNA analysis. We thank R. G. E. Murray, L. V. Holdeman, I. M. Robinson, and M. P. Bryant for advice regarding the taxonomy of $R$. cecicola.

T.B.S. was supported by Public Health Service National Research Service Award AI 06110 from the National Institute of Allergy and Infectious Diseases. This research was also supported by Public Health Service Project Grant AI 11858 from the National Institute of Allergy and Infectious Diseases.

\section{LITERATURE CITED}

1. Back, W., and E. Stockebrandt. 1978. DNS/DNS-Homologiestudien innerhalb der Gattung Pediococcus. Arch. Microbiol. 118:79-85.

2. Bryant, M. P. 1974. Genus Butyrivibrio Bryant and Small 1956, p. 420-421. In R. E. Buchanan and N. E. Gibbons (ed.), Bergey's manual of determinative bacteriology, 8 th ed. The Williams \& Wilkins Co., Baltimore.

3. Bryant, M. P. 1974. Genus Succinivibrio Bryant and Small 1958, p. 422. In R. E. Buchanan and N. E. Gibbons (ed.), Bergey's manual of determinative bacteriology, 8 th ed. The Williams \& Wilkins Co., Baltimore.

4. Bryant, M. P. 1974. Genus Succinomonas Bryant, Small, Bouma and Chu 1958, p. 422-423. In R. E. Buchanan and N. E. Gibbons (ed.), Bergey's manual of determinative bacteriology, 8th ed. The Williams \& Wilkins Co., Baltimore.

5. Bryant, M. P. 1974. Genus Selenomonas von Prowazek 1913, p. 424-426. In R. E. Buchanan and N. E. Gibbons (ed.), Bergey's manual of determinative bacteriology, 8th ed. The Williams \& Wilkins Co., Baltimore.

6. Caldwell, D. R., and M. P. Bryant. 1966. Medium without rumen fluid for nonselective enumeration and isolation of rumen bacteria. Appl. Microbiol. 14:794-801.

7. Cheng, K.-J., and J. W. Costerton. 1977. Ultrastructure of Butyrivibrio fibrisolvens: a gram-positive bacterium? J. Bacteriol. 129:1506-1512.

8. Cwyk, W. M., and E. Canale-Parola. 1979. Treponema succinifaciens $\mathrm{sp}$. nov., an anaerobic spirochete from the swine intestine. Arch. Microbiol. 122:231-239.
9. De Ley, J. 1970. Reexamination of the association between melting point, buoyant density, and chemical base composition of deoxyribonucleic acid. J. Bacteriol. 101:738-754.

10. Gordon, J. H., and R. Dubos. 1970. The anaerobic bacterial flora of the mouse cecum. J. Exp. Med. 132:251-260.

11. Holdeman, L. V., and W. E. C. Moore. 1974. Family I. Bacteroidaceae Pribram 1933, p. 384, In R. E. Buchanan and N. E. Gibbons (ed.), Bergey's manual of determinative bacteriology, 8 th ed. The Williams \& Wilkins Co., Baltimore.

12. Holdeman, L. V., and W. E. C. Moore. 1974. Genus I. Bacteroides Castellani and Chalmers 1919, p. 385-404. In R. E. Buchanan and N. E. Gibbons (ed.), Bergey's manual of determinative bacteriology, 8th ed. The Williams \& Wilkins Co., Baltimore.

13. Holdeman, L. V., and W. E. C. Moore. (ed.). 1975. Anaerobe laboratory manual, 3 rd ed. Anaerobe Laboratory, Virginia Polytechnic Institute and State University, Blacksburg.

14. Hungate, R. E. 1969. A roll tube method for cultivation of strict anaerobes, p. 117-132. In J. R. Norris and D. W. Ribbons (ed.), Methods in microbiology, vol. 3B. Academic Press, Inc., New York.

15. Kingsley, V. V., and J. F. M. Hoeniger. 1973. Growth, structure, and classification of Selenomonas. Bacteriol. Rev. 37:479-521.

16. Lee, S. Y., M. S. Mabee, and N. O. Jangaard. 1978. Pectinatus, a new genus of the family Bacteroidaceae. Int. J. Syst. Bacteriol. 28:582-594.

17. Marmur, J., and P. Doty. 1962. Determination of the base composition of deoxyribonucleic acid from its thermal denaturation temperature. J. Mol. Biol. 5:109-118.

18. McInerney, M. J., M. P. Bryant, R. B. Hespell, and J. W. Costerton. 1981. Syntrophomonas wolfei gen. nov., sp. nov., an anaerobic, syntrophic fatty acid-oxidizing bacterium. Appl. Environ. Microbiol. 41:1029-1039.

19. Moore, W. E. C., and L. V. Holdeman. 1974. Genus II. Fusobacterium Knorr 1922, p. 404-416. In R. E. Buchanan and N. E. Gibbons (ed.), Bergey's manual of determinative bacteriology, 8th ed. The Williams \& Wilkins Co., Baltimore.

20. Postgate, J. R. 1974. Genus Desulfovibrio Kluyver and van Niel 1936, p. 418-420. In R. E. Buchanan and N. E. Gibbons (ed.), Bergey's manual of determinative bacteriology, 8th ed. The Williams \& Wilkins Co., Baltimore.

21. Reynolds, E. S. 1963. The use of lead citrate at high $\mathrm{pH}$ as an electron opaque stain in electron microscopy. J. Cell. Biol. 17:208-212.

22. Robinson, I. M., and A. E. Ritchie. 1981. Emendation of Acetivibrio and description of Acetivibrio ethanolgignens, a new species from the colons of pigs with dysentery. Int. J. Syst. Bacteriol. 31:333-338.

23. Rogosa, M. 1974. Genus III. Leptotrichia Trevisan 1879 , p. 416-418. In R. E. Buchanan and N. E. Gibbons (ed.), Bergey's manual of determinative bacteriology, 8th ed. The Williams \& Wilkins Co., Baltimore.

24. Rogosa, M., and M. P. Bryant. 1974. Genus Lachnospira Bryant and Small 1956, p. 423-424. In R. E. Buchanan and N. E. Gibbons (ed.), Bergey's manual of determinative bacteriology, 8th ed. The Williams \& Wilkins Co., Baltimore.

25. Rosebury, T. 1962. Microorganisms indigenous to man. McGraw-Hill Book Co., New York.

26. Salanitro, J. P., and P. A. Muirhead. 1975. Quantitative method for the gas chromatographic analysis of shortchain monocarboxylic and dicarboxylic acids in fermentation media. Appl. Microbiol. 29:374-381.

27. Savage, D. C. 1977. Microbial ecology of the gastrointestinal tract. Annu. Rev. Microbiol. 31:107-133.

28. Skerman, V. B. D. 1969 . Abstracts of microbiological methods. Wiley-Interscience, New York.

29. Wiegel, J. 1981. Distinction between the Gram reaction and the Gram type of bacteria. Int. J. Syst. Bacteriol. $31: 88$. 